RESEARCH ARTICLE

\title{
Genetic Analysis and Seed Polymorphism in Inter sub Specific Cross of Blackgram (Vigna mungo (L.) Hepper)
}

\author{
Manju Devi $\mathrm{S}^{1 *}$, Jayamani $\mathrm{P}^{1}$ and Kumar $\mathrm{M}^{2}$ \\ $1^{*}$ Department of Pulses, Centre for Plant Breeding and Genetics, Tamil Nadu Agricultural University, Coimbatore-641003 \\ 2 Tamil Nadu Agricultural University, Coimbatore-641003
}

\begin{abstract}
The present study was carried out using 189 pre-breeding lines from the cross VBN (Bg) 5 and Vigna mungo var silvestris 22/10 to study the genetic variability for nine yields and six seed traits. Significant variability was observed for all the traits studied. The phenotypic coefficient of variation (PCV) was higher than the genotypic coefficient of variation (GCV) for all the 15 traits. High PCV was observed for number of pods per plant, seed volume, and single plant yield. The moderate to high GCV was exhibited for hundred seed weight, plant height, number of pods per plant, seed volume, and single plant yield. The heritability estimates were high for pod length, plant height, seed length, hundred seed weight, single plant yield, bulk density, seed length-width ratio and seed width. The traits viz., plant height, hundred seed weight, and single plant yield showed high heritability along with high genetic advance as per cent of mean respectively, which might be due to additive gene action. Hence, these traits could act as a better source for the breeding programme for evolving high-yielding bold seeded varieties.
\end{abstract}

Keywords : Blackgram; Pre-breeding lines; Yield- seed traits; Genetic variability.

\section{INTRODUCTION}

Blackgram (Vigna mungo (L.) Hepper), also known as urdbean, is an essential short duration, self-pollinated, diploid $(2 n=22)$ legume that belongs to the family Leguminaceae with a genome size of 574 Mbp (Gupta et al., 2008). It contains a perfect combination of all major nutrients with a protein content of 25 per cent and can be used as a source of dietary protein next to soybean. The dry seed is a good source of phosphorous. It is used in combination with rice or wheat because it complements the essential amino acid such as lysine, methionine, and cysteine. The yield of blackgram is low due to the absence of stable cultivars and the influence of pests and diseases, which affect the growth and productivity in blackgram (Souframanian and Gopalakrishnan, 2004).

Genetic variability for yield and yield contributing characters were lost in the process of crop evolution, which results in the narrowing of the genetic base. Yield, a complex trait governed by many genes, is interlinked with other traits and hence its performance can be improved by the selection of traits that are highly heritable and correlated with yield. The nature and extent of the breeding programme depend on the variability present in the base population. The creation of variability can be achieved by selecting suitable parents, which helps in further improvement of yield attributing traits (Falconer, 1981). The visual appearance of seed fetches high market value and increases consumer preference. Seed size improvement is also one of the most important breeding objectives that directly relate to the yield of the crop. Understanding genetic variability parameters and heritability are essential in the breeding programme for selecting parents and to deciding on an appropriate breeding strategy for crop improvement (Appalaswamy and Reddy, 2004). Considering the available literature, the present study was undertaken to study the magnitude of genetic variability that is heritable among the lines of blackgram.

\section{MATERIALS AND METHODS}

A field trial using a total of 189 lines obtained from the cross VBN (Bg) 5 and Vigna mungo var silvestris 22/10 $\left(\mathrm{F}_{9}\right)$ was raised in randomized block design during Kharif, 2019 at the Department of Pulses, Centre for Plant Breeding and Genetics, Tamil Nadu Agricultural University, Coimbatore in two replications with a spacing of $30 \times 10 \mathrm{~cm}$ in a row of 4-meter length. The agronomic practices were followed as per the recommendations. Observations on nine yield attributing traits were taken on three randomly selected plants in each replication viz., 
days to 50 per cent flowering, plant height $(\mathrm{cm})$, number of primary branches per plant, number of pods per cluster, number of pods per plant, pod length $(\mathrm{cm})$, number of seeds per pod, single plant yield (g) and hundred seed weight (g). Along with these traits, six seed related traits viz., seed length $(\mathrm{mm})$, seed width $(\mathrm{mm})$, seed length-width ratio, seed thickness $(\mathrm{mm})$, seed volume $(\mathrm{mL})$, and bulk density $\left(\mathrm{g} / \mathrm{cm}^{3}\right)$ were also taken for genetic variability studies.

Seed length depicts the distance from the top of the seed to its bottom, whereas; seed width was examined by measuring the distance from the hilum of the seed to its opposite side using graphical method. Seed thickness was measured using Vernier caliper $(0-150 \mathrm{~mm})$ by placing it between sides of the hilum. The seed length/width ratio was measured by dividing the length by its width. The bulk density was the ratio of the mass of the seed sample to its total volume. In the predetermined quantity of water, the known number of seeds was taken and the rise in the volume of water in the measuring cylinder was measured as seed volume.

The statistical significance (ANOVA) was performed using the software GENRES 7.01 developed by Pascal Intl. software solutions using the formula suggested by Panse and Sukhatme (1967). The genetic variability measures viz., phenotypic coefficient of variation (PCV), genotypic coefficient of variation (GCV), genetic advance as per cent of mean was calculated as per the formula provided by Johnson et al. (1955). Broad sense heritability was calculated using the formula given by Lush (1940).

\section{RESULTS AND DISCUSSION}

Analysis of variance showed significant differences for all the traits studied among the lines which indicated a sufficient amount of variability. A wide range of variations was observed for all the studied traits. The wider range for mean values was observed for yield attributing traits viz., number of pods per cluster (2.17-4.50), number of pods per plant (6.00-19.17), number of seeds per pod (4.837.67), single plant yield (1.12-4.77 g), hundred seed weight (2.90-5.98 g), seed length (4.25-5.20 mm), seed width (3.30-4.15 mm), seed length-width ratio (1.07-1.52), seed thickness (2.84-3.87 mm), seed volume (0.75-3.00 $\mathrm{ml})$ and bulk density (0.43-0.71 $\left.\mathrm{g} / \mathrm{cm}^{3}\right)$. Sowmini and Jayamani (2013) observed a broad range of variations of plant height, number of clusters per plant, number of pods per plant, and single plant yield. The traits viz., plant height, pod length, number of pods per plant, and seed yield per plant had ample range of variation as noticed by Gowsalya et al. (2016) in blackgram. Patel et al. (2020) found days to 50 per cent flowering, plant height, number of pods per plant, seed yield per plant, and days to maturity that had large range of variation in blackgram. The interspecific hybridization helps to exploit transgressive segregants for improving yield attributing traits.

A total of 86 lines for single plant yield and 84 lines for hundred seed weight exhibited higher mean values than the general mean. For seed-related traits, 92 lines for seed length, 84 lines for seed width, and 92 lines for seed thickness exceeded the corresponding general mean values. Twentyseven lines were found to be common in these traits which could be further exploited to increase the size of the seed and also to provide different grading systems to differentiate the seed size in black gram. The other yield-related traits viz., number of pods per plant, number of seeds per pod, and pod length also exhibited more mean values than general mean and 36 lines found to be observed as common among these traits, which could help to increase the yield when an indirect selection was made (Table. 1). Vinoth and Jayamani (2014) found 88 lines as transgressive segregants for single plant yield in blackgram. Harshita and Jayamani (2020) observed 31 transgressive lines for single plant yield in interspecific lines of green gram. Kuralarasan and Jayamani (2021) observed 30 lines for number of pods per plant, 98 lines for number of seeds per pod, 36 lines for single plant yield as transgressive segregants in blackgram.

The phenotypic coefficient of variation was higher than the genotypic coefficient of variation for all the traits observed. This revealed that the existing variation is due to the genetic constitution of genotypes and added with environmental variance. High estimates of genotypic coefficient of variation were observed for single plant yield (28.81\%) whereas, moderate GCV was exhibited by hundred seed weight (12.00\%), plant height (14.22 $\%)$, number of pods per plant (18.65\%), and seed volume (18.73\%). Panigrahi et al. (2014) found high GCV for yield per plant, number of pods per plant, number of clusters per plant, and number of primary branches per plant in blackgram. The traits viz., plant height, and the number of clusters per plant had moderate GCV in blackgram (Rolaniya et al., 2017). Single plant yield, number of pods per plant, and number of clusters per plant exhibited high GCV (Sushmitharaj et al., 2018) in black gram. The traits like grain yield, number of pods per plant, and plant height showed moderate GCV which was observed by Anuradha et al. (2020) in blackgram. Joshna et al. (2021) observed moderate GCV for the number of clusters per plant, seed yield per plant, and the number of pods per plant in blackgram.

The PCV was high for the number of pods per plant (26.95\%), seed volume (27.82\%), and 
single plant yield (30.22 \%). Gomathi et al. (2020) observed high PCV for single plant yield, number of clusters per plant, number of pods per plant, number of primary branches per plant, and number of seeds per pod. The traits, seed yield and harvest index showed high PCV as observed by Saran and Sharma (2021) in blackgram. Latha et al. (2013) observed high PCV for seed volume in horsegram.
The difference between PCV and GCV was high for seed volume, followed by a number of pods per cluster, indicating a higher level of environmental influence on these traits. The lowest difference was found for seed length-width ratio and hundred seed weight. Teja et al. (2021) observed the lowest difference between GCV and PCV for days to 50 per cent flowering, followed by biological yield, seed index, pod length, and plant height.

Table 1. Genotypic coefficient of variation, Phenotypic coefficient of variation, Heritability (Broad sense), genetic advance as per cent of mean in blackgram.

\begin{tabular}{|c|c|c|c|c|c|c|c|c|c|}
\hline Characters & Mean & $\begin{array}{l}\text { Number of } \\
\text { lines above } \\
\text { mean values }\end{array}$ & Range & $\begin{array}{l}\text { GCV } \\
(\%)\end{array}$ & $\begin{array}{l}\text { PCV } \\
(\%)\end{array}$ & $\begin{array}{l}\text { Heritability } \\
\text { (\%) }\end{array}$ & $\begin{array}{c}\text { Genetic } \\
\text { advance as } \\
\text { per cent of } \\
\text { mean }\end{array}$ & Skewness & Kurtosis \\
\hline $\begin{array}{l}\text { Days to } 50 \text { percent } \\
\text { flowering }\end{array}$ & 40 & 41 & $37-43$ & 1.8 & 3.45 & 27.05 & 1.92 & 0.34 & -0.33 \\
\hline Plant height (cm) & 24.17 & 94 & $15.37-32.75$ & 14.22 & 15.35 & 85.82 & 27.14 & 0.33 & -0.31 \\
\hline $\begin{array}{l}\text { Number of primary } \\
\text { branches per plant }\end{array}$ & 2.54 & 87 & $2.00-3.00$ & 6.17 & 13.17 & 21.97 & 5.96 & -0.08 & -0.74 \\
\hline $\begin{array}{l}\text { Number of pods per } \\
\text { cluster }\end{array}$ & 3.26 & 98 & $2.17-4.50$ & 9.14 & 16.55 & 30.5 & 10.4 & 0.27 & 0.16 \\
\hline $\begin{array}{l}\text { Number of pods per } \\
\text { plant }\end{array}$ & 11.96 & 94 & $6.00-19.17$ & 18.65 & 26.95 & 47.88 & 26.58 & 0.32 & -0.43 \\
\hline Pod length (cm) & 4.33 & 89 & $3.35-5.23$ & 6.95 & 7.54 & 84.81 & 13.18 & -0.04 & 0.47 \\
\hline $\begin{array}{l}\text { Number of seeds } \\
\text { per pod }\end{array}$ & 6.41 & 86 & $4.83-7.67$ & 5.33 & 8.06 & 43.74 & 7.27 & 0.06 & 0.35 \\
\hline Single plant yield (g) & 2.47 & 86 & $1.12-4.77$ & 28.81 & 30.22 & 90.88 & 56.58 & 0.46 & -0.28 \\
\hline $\begin{array}{l}\text { Hundred seed } \\
\text { weight (g) }\end{array}$ & 4.23 & 84 & $2.90-5.98$ & 12 & 12.6 & 90.81 & 23.57 & 0.41 & 0.07 \\
\hline Seed length $(\mathrm{mm})$ & 4.74 & 92 & $4.25-5.20$ & 4.11 & 4.33 & 90.5 & 8.07 & 0.26 & -0.88 \\
\hline Seed width (mm) & 3.69 & 84 & $3.30-4.15$ & 5.90 & 6.01 & 96.41 & 11.93 & 0.39 & -1.10 \\
\hline $\begin{array}{l}\text { Seed length width } \\
\text { ratio }\end{array}$ & 1.30 & 87 & $1.07-1.52$ & 6.85 & 7.05 & 94.41 & 13.71 & -0.12 & -0.54 \\
\hline $\begin{array}{l}\text { Seed thickness } \\
(\mathrm{mm})\end{array}$ & 3.27 & 92 & $2.84-3.87$ & 4.38 & 7.35 & 35.48 & 5.37 & 0.16 & -0.33 \\
\hline Seed volume (ml) & 1.93 & 105 & $0.75-3.00$ & 18.73 & 27.82 & 45.36 & 25.99 & -0.002 & -0.41 \\
\hline $\begin{array}{l}\text { Bulk density (g/ } \\
\text { cm3) }\end{array}$ & 0.65 & 80 & $0.43-0.71$ & 5.48 & 5.66 & 93.93 & 10.94 & -2.02 & 9.19 \\
\hline
\end{tabular}

The phenotypic variation observed does not transmit entirely to the subsequent generation. Hence, it is necessary to classify the observed variability which is heritable or not. Heritability provides information regarding traits that are transmitted to the next generation, which determines the response to selection. The traits viz., pod length (84.81\%), plant height (85.82\%), seed length (90.50\%), hundred seed weight (90.81\%), single plant yield (90.88\%), bulk density (93.93\%), seed length-width ratio (94.41\%) and seed width (96.41 $\%)$ exhibited high heritability whereas, moderate heritability was observed for a number of pods per cluster (30.5\%), seed thickness (35.48\%), number of seeds per pod (43.74\%), seed volume (45.36\%) and number of pods per plant (47.88 \%). The low heritability was noticed for the number of primary branches per plant (21.97\%) and days to 50 per cent flowering (27.05\%). Kumar et al. (2015) observed high heritability for pod length, seed yield, plant height, hundred seed weight, number of clusters per plant, pod weight, and total biomass in blackgram. Bandi et al. (2018) observed high heritability for pod length, hundred seed weight, days to 50 per cent flowering, number of pods per plant, days to maturity, grain yield per plant, number of clusters per plant, plant height, and number of branches per plant in blackgram. Manju Devi and Jayamani (2018) envisioned moderate heritability for a number of seeds per pod in cowpea. Sulistyo et al. (2021) 
observed high heritability for seed width, width thickness ratio, seed thickness, length-thickness ratio and hundred seed weight in soybean.

The frequency distribution estimated by thirdorder statistics viz., skewness and kurtosis depicts the nature of gene action and the number of genes involved in controlling the traits. It also helps to select plants with the desirable trait of interest. Kurtosis describes the variation in the peakedness of the curve (Pearson, 1905). In this study, positive skewness was observed for hundred seed weight, single plant yield, and seed width. It is indicated that more proportion of plants with low values for these traits are available in this population. In the case of kurtosis, all traits exhibited mesokurtic distribution which indicates normal distribution for these traits except pod length, number of seeds per pod, and bulk density which expressed leptokurtic distribution. Harshita and Jayamani (2020) observed mesokurtic distribution for all the traits except for days to 50 per cent flowering, plant height, and hundred seed weight in interspecific lines of greengram.

The heritability alone could not help in determining the breeding programme. Along with heritability, genetic advance as per cent of mean helps predict the genetic control of any particular trait. These two parameters are important to rule out the environmental influence from the total variability, which ultimately increases the effectiveness of selection. The higher estimate of heritability along with genetic advance as per cent of mean was observed by plant height (85.82, 27.14), hundred seed weight $(90.81,23.57)$, and single plant yield $(90.88,56.58)$, respectively. High heritability along with moderate genetic advance as per cent of mean was recorded for pod length $(84.81,13.18)$, bulk density $(93.93,10.94)$, seed length-width ratio (94.41, 13.71), and seed width (96.41, 11.93). Hence, it is concluded that the above characters are governed by additive genes in which selection can help in the improvement of such traits. Panigrahi et al. (2014) visualized that yield per plant, number of pods per plant, plant height, number of clusters per plant, hundred seed weight, and pod length had high heritability and high genetic advance as per cent of mean in blackgram. Vinoth and Jayamani (2014) observed high heritability and high genetic advance as per cent of mean for number of branches per plant, number of pods per plant, plant height, single plant yield, and hundred seed weight in blackgram. High heritability with moderate genetic advance as per cent of mean was observed for plant height, harvest index and biological yield in blackgram by Aftab et al. (2018).

\section{CONCLUSION}

Based on the present study, the direct selection can be practiced for yield contributing characters viz., number of pods per cluster, number of pods per plant, number of seeds per pod, single plant yield, and hundred seed weight. The seed characters viz., seed length, seed width, length-width ratio, volume, and bulk density play an important role in the improvement of the physical properties of the seed. These physical properties of the seed had a wider role in engineering aspects for properly designing the post-harvest processing equipment. Thus the seed traits seed width and seed length-width ratio simple selection for these traits provides scope for further improvement of seed traits in blackgram. The lines showing high length-width ratio indicate seed boldness which can be further utilized in breeding programme for developing varieties with high market value.

\section{REFERENCES}

Aftab, N., Lal, G. M., Sheera, A., Bose, N. C. and A. M. Tripathi. 2018. Evaluation of genetic variability in black gram (Vigna mungo L. Hepper) germplasm. J. Plant Dev., 10(8): 445-452.

Anuradha, N., Patro, T. S. S. K., Triveni, U. and P. J. R. S. Rajkumar.2020. Character association and variability studies in black gram advanced breeding lines. J. pharmacogn. phytochem., 9(1): 1880-1882.

Appalaswamy and Reddy. 2004. Genetic divergence and heterosis studies of mungbean (Vigna radiata (L.) Wilczek). Legume Res., 21:115-118.

Bandi, H. R. K., Rao, K. N., Krishna, K. V. and K. Srinivasulu. 2018. Variability, heritability and genetic advance for quantitative characters in rice fallow black gram [Vigna mungo (L.) Hepper]. Int. j. curr. microbiol. app. sci., 7(2): 171-176.

Falconer, D.S. 1981. Introduction to Quantitative genetics, 3rd ed. Longman, New York. 340

Gomathi, D., Shoba, D., Ramamoorthy, V. and M. A. Pillai. 2020. Studies on Variability, Heritability, Correlation and Path Analysis in Segregating Population of Black Gram [Vigna mungo (L.) Hepper]. Legume Res., 1-5.

Gupta, S.K., Souframanien, J. and T. Gopalakrishna. 2008. Construction of a genetic linkage map of black gram, Vigna mungo (L.) Hepper, based on molecular markers and comparative studies. Genome Res., 51: 628-637.

Gowsalya, P., Kumaresan, D., Packiaraj, D. and Kannanbapu, J. 2016. Genetic variability and character association for biometrical traits in blackgram (Vigna mungo (L.) Hepper). Electron. J. Plant Breed., 7(2): 317-324.

Harshitha, G. P. and P. Jayamani. 2020. Genetic Analysis in Pre-breeding Lines of Greengram (Vigna radiata (L.) Wilczek.). Int.j.curr.microbiol.app.sci,. 9(07): 2791-2798.

Johnson, H. W., Robinson, H. F. and R. E.Comstock. 1955. Estimates of genetic and environmental variability in soybeans. J. Agron., 47(7): 314-318. 
Joshna, K., Lavanya, G. R. and Jemima Das, M. 2021. Estimation of Genetic Variability and Character Association for Yield Characters in Blackgram (Vigna mungo (L.) Hepper). Int.J.Curr.Microbiol.App. Sci., 10(02): 836.

Kumar, G. V., Vanaja, M., Lakshmi, N. J. and M. Maheswari. 2015. Studies on variability, heritability and genetic advance for quantitative traits in black gram [Vigna mungo (L.) Hepper]. Agric. Res. J., 52(4): 28-31.

Kuralarasan, V. and P. Jayamani. 2021. Relationship between yield and its component traits in inter sub- specific derivatives of Vigna mungo $x$ Vigna mungo var. silvestris. Int. j. curr. microbiol. app. sci., 10(03): 1683-1689.

Latha, M., Suma, A., Asha, K. I., Dwivedi, N. K., Mani, S. and A. Indiradevi. 2013. Seed polymorphism in South Indian horsegram (Macrotyloma uniflorum (Lam.) Verdc.): a comprehensive study. J Appl Biol Biotechnol., 1(4): 001-006

Lush, J. L. 1940. Intra-sire correlations or regressions of offspring on dam as a method of estimating heritability of characteristics. Anim. Sci. J., (1): 293-301

Manju Devi. S. and P. Jayamani. 2018. Genetic variability, heritability, genetic advance studies in cowpea (Vigna unguiculata (L.) Walp). Electron. J. Plant Breed., 9(2): 476-481.

Panigrahi, K. K., Baisakh, B., Kar, M. And A. Mohanty. 2014. Genetic divergence in mutants and land races of blackgram (Vigna mungo [L.] Hepper) from Odisha. Electron. J. Plant Breed., 5(3): 567-572.

Panse, V. G. and P. V. Sukhatme. 1967. Statistical methods of agricultural workers. 2nd Endorsement. ICAR Publication, New Delhi, India: 381.

Pearson, K. 1905. Skew variation, a rejoinder. Biometrika., 4:169-212.
Patel, N. and Bala, M. 2020. Genetic variability study for yield and its components in black gram [Vigna mungo (L.) Hepper]. J. pharmacogn.phytochem., 9(4): 2061-2064.

Rolaniya, D. K., Jinjwadiya, M. K., Meghawal, D. R. and Lal, G. 2017. Studies on genetic variability in Black gram (Vigna mungo L. Hepper) germplasm. J. pharmacogn. phytochem., 6(4): 1506-1508.

Saran, R. and Sharma. 2021. Evaluation of genetic parameters in black gram [Vigna mungo (L.) Hepper] for seed yield and its related traits. TheJ. Pharm. Innov., 10(7): 364-366.

Sowmini, K. and P. Jayamani. 2013. Genetic variability studies for yield and its component traits in RIL population of blackgram (Vigna mungo (L.) Hepper). Electron. J. Plant Breed., 4(1): 1050-1055.

Sulistyo, A., Mejaya, M. J. and N. Nugrahaeni. 2021. Determination of Genetic Parameters of Seed Characteristics in Edible soybean. Legume Res., 44(5).

Sushmitharaj, D. V., Shoba, D. And M. A. Pillai. 2018. Genetic variability and correlation studies in black gram (Vigna mungo [L.] hepper) with reference to YMV resistance. Int. j. curr. microbiol. app. sci., 2849-2856.

Souframanien, J. and T. Gopalakrishna. 2004. A comparative analysis of genetic diversity in blackgram genotypes using RAPD and ISSR markers. Theor. Appl. Genet., 109: 1687-1693.

Teja, M. K. V. and Lal, G. 2021. Study of genetic variability and character association for yield and yield related traits in $\mathrm{f} 3$ generation of blackgram (Vigna mungo (L.) Hepper). Int.J.Environ., 6: 3.

Vinoth R. and P. Jayamani. 2014. Genetic variability studies for yield and its component traits in inter sub specific RIL population of blackgram (Vigna mungo (L.) Hepper). Biosci. Trends., 7(2): 243245. 